\title{
BEYOND THE VIRUS: \\ There cannot be a pandemic without the State
}

\author{
Rodrigo Toniol
}

I Professor of Anthropology at Unicamp and the current president of the Association of Social Scientists of Religion of Mercosur. Campinas/SP - Brasil

\begin{abstract}
Abstract: This paper starts with the acknowledgment of the importance of the State as an order-ing principle for the experience of the pandemic. Such a statement implies two complementary movements - although these will not be exhausted in the following pages. Firstly, it means that the notion of pandemic itself has a genealogy. It means that its emergence is the result of a histor-ical process and of specific political configurations, which are strongly associated with the con-solidation of the modern State. Second, if the treatment of the notion of a pandemic needs to be considered on the basis of its relationship with the state, an analysis of "pandemic" processes is undoubtedly a political debate. I finish by suggesting benefits of a possible approximation be-tween the notion of environmental justice and the critical principles for the analysis of the pan-demic that we are facing.
\end{abstract}

Keywords: State, environmental justice, nature, Church

São Paulo. Vol. 23, 2020

Debating ideas

The COVID-19 epoch: Interdisciplinary research towards a new just and sustainable ethics

DOI: http://dx.doi.org/10.1590/1809-4422asoc20200073vu2020L3ID 


\section{Introduction}

Among the possible developments of the Covid-19 pandemic at the international level This paper begins with an acknowledgment of the importance of the State as an ordering princi-ple for the experience of a pandemic. Such a statement implies two complementary movements - although not exhaustively discussed in the following pages. Firstly, it means that the notion of a pandemic itself has a genealogy. This means that its emergence is the result of an historical pro-cess and of specific political configurations which are strongly associated with the consolidation of the modern State. Secondly, if the emergence of the notion of a pandemic needs to be thought of as being based on its relationship with the State, the analysis of "pandemic" processes places the need for considering the socially unequal effects of natural phenomena. I conclude by sug-gesting the benefits of a possible approximation between the notion of environmental justice and the critical principles necessary for the analysis of the pandemic that we are facing.

\section{Democratic nature? Risk and vulnerabilities}

A pandemic is not simply created by a powerful contagious biological agent putting mil-lions of lives at risk. Pandemics are also the result of laws, decrees, official announcements and collective interviews that slowly classify and name previously disconnected facts: a fish market in a city in China; South Korean evangelical pastors; the consumption of wild animals; a soccer game in Italy; a Brazilian tourist in Egypt. Seemingly random, this combination of facts starts acquiring coherence as we add some sort of "pandemic lingua franca" to flatten the curve: Coro-navirus; lockdown; COVID-19; Wuhan; World Health Organization. The idea that we are facing a pandemic depends on the capability of coordination and ordering in this complex ensemble of phenomena. Highlighting that pandemics are related to the intensification of commerce and in-tercontinental traveling, which benefits viral dissemination throughout the world, helps us under-stand the epidemiological dynamic. However, it can render an equally relevant dimension hollow; the history of pandemics walks alongside the history of the modern State.

Without the State, without the element that builds coherence and enacts it, there can be no pandemic. That does not mean that the devastating biological reality of the virus is being de-nied, nor does it suggest embarking on the dangerous adventures of conspiracy theories. Rather, what is at stake here is affirming the complexity of a pandemic, which depends not only on the circulation of a biological agent, but also on an act of "enaction," which modifies the nature of the phenomenon.

The historical registry of pandemics around the world grows as the State is established as the ordering agent of life. Formerly, and from existing evidence, there used to be phenomena of generalized mortality that today would be recognized as a pandemic, but in these cases, the or-dering agent was different -- the church. Therefore, what used to devastate the medieval world were not pandemics, but plagues. The historical affinity

1- My reference here is the term enact, used by Annemarie Mol (2002) to show that things/objects exist if the practices that work for its production are articulated. Enact is the act that establishes a reality. 
between the State and pandemics testi-fies to the collapse of the ability of the church in enacting plagues. The church was responsible for the moral management of explanations of deaths due to the plague; it was up to the church to attribute coherence to the divine punitive, justifying each death for dishonorable attitudes of the individual or their group.

The moralities of a pandemic are not the same as of a plague, but both share the perverse notion that the individual attitude is the key explanatory element to survival or death. It is once more the two-sided coin of the ideology of individualism in action: salvation depends on private action, just as the responsibility for death is invariable.

What the pandemic in the 21 st century keeps revealing is that if there is not a biological selectivity, structural inequalities quickly show up those bodies that are able to protect them-selves, or not, from the risks of contamination.

The fantasy of a "democratic virus," as some analysts insist as being true, is either a symp-tom of a wish that nature accomplishes the principles that we see being increasingly threatened, or a result of myopia that insists on not recognizing that specific social groups will have to dis-proportionately deal with the consequences of the epidemic. The distribution map of COVID-19 in Rio de Janeiro spotlights this situation in an exemplary manner. Having had the first cases happen in Zona Sul and Barra (which are wealthy neighborhoods), the dissemination and explo-sion of contagion does not happen on city streets, but rather in the hills of the favelas, where there exists no possibility of isolation, where the sanitary conditions have always been precarious - here, medical support does not exist. It is here that, once more, the pandemic needs to be un-derstood as coming from its counterpart, the State.

The pandemic has become a globally unavoidable event, imposing some form of systemat-ic management of the dangers and insecurities introduced and induced by it. This statement about danger management is the very definition of risk made by German sociologist Ulrich Beck (2011). The risk is related to the management of the danger; it is an anticipatory condition of a catastrophic event. Dealing with risk in this text allows me to emphasize two important dimen-sions of my argument. The first, which I will explore further, concerns the social vulnerabilities that expose the asymmetries in the response capacity which actors have according to their class, ethnic-racial make up, and gender conditions. The second dimension that the theme of risk em-phasizes is related to the contribution of theorist Roger Kasperson (1988). Kasperson formulated the notion of social amplification of risk that denotes the phenomenon by which information pro-cesses, institutional structures, social-group behavior and individual responses shape the social experience of risk, thereby contributing to risk consequences.

The interaction between risk and social process makes clear that risk has meaning only to the extent that it treats how people think about the world and its relationships. Thus, there is no such thing as true and distorted risk. Rather the information system and characteristics of public response that compose social amplification are essential elements in determining the na-ture and magnitude of the risk. Kasperson (1988, p. 181) 
Risk, therefore, is constituted by the way in which a wide range of intermediaries align to produce it. In the COVID-19 pandemic, the State is a fundamental agent in assessing the magni-tude of the risk.

Modernity brought to the State the possibility of transforming the shape of its govern-ment and the management of lives. As the philosopher Michael Foucault argued, it is no longer about exercising a sovereign power that determines death when it deems it necessary; a power that decides who will live and who will die. In modernity, the State exercises biopolitics, a way of sovereignty based on management of the lives of its people: the power over life and death (Foucault 2008). We will be facing the rawness of biopolitics over the next few months. We will encounter the evidence of a situation in which even the possible victory of medical technology over the virus, with the discovery of a vaccine, for example, will not end the battle. It will con-tinue operating from the inequalities that currently exist. And that brings us back to the issue of vulnerabilities.

The intricate relationship between nature, the State, and inequality remind us of a current notion within the ecological debate which, in this moment, also appears to help us evaluate the impacts of the pandemic: I am referring to the notion of environmental justice. It is based on this notion that the socially unequal nature of the conditions of access to protection against environ-mental disasters is outlined. Therefore, it is acknowledged that it would not be possible to sepa-rate the environmental problems from the way in which the power over political, material and symbolic resources are unequally distributed. Simultaneous forms of oppression would be respon-sible for environmental injustices resulting from the inseparable nature of class, gender and racial oppression (ACSELARD, 2002).

Remembering this notion is convenient for two reasons. First, because it helps us move away from the idea of a democratic nature, where phenomena, whether it is environmental catas-trophes or the dissemination of a virus throughout the world, would result in equally distributed effects, or effects that would distinctly affect the population for reasons that are foreign to the social structures. Second, it helps us to move away from the notion that the exposure to greater or smaller risks of these situations is a deliberate and conscious act, where responsibility is exclusive to the ones that are facing it: neither one nor the other. Environmental justice is a notion that works as a reminder that there are no natural facts where effects do not vary because of social reasons. We seem to be facing a similar phenomenon with this pandemic. Preliminary data about the people that are most impacted by Coronavirus in the United States and in Brazil have some convergence. In both cases, what stands out are higher death rates amongst the populations of African descent. In New York, currently the epicenter of the virus, one of the most affected dis-tricts is the Bronx, which has the highest percentage of African Americans and the lowest wages in the city. In this region, the virus attacks in a disproportional manner: this neighborhood consti-tutes just $17 \%$ of people from New York, yet has $23 \%$ of the recorded deaths. The disparity re-peats throughout the city, where African Americans represent 22\% of the population and 28\% of the deaths. In New York State, excluding the city, they represent $9 \%$ of the population and $17 \%$ of the deaths. 
This situation is repeated in other states. In Michigan, the black population repre-sents just $14 \%$ of the population but constitutes $40 \%$ of the deaths. In Louisiana, the disparity is even more relevant: African Americans comprise 32\% of the population - yet they represent $70 \%$ of total deaths.

In Brazil, even though they are a minority within the registry of people affected by the disease, black and mixed-race people represent almost 1 in every 4 Brazilians hospitalized with the severe acute respiratory syndrome $(23,1 \%)$, but this representation reaches lof every 3 of the deaths for COVID-19 (32,8\%). The explanation lies in the epidemiological vulnerabilities. Its distribution also reflects social inequalities. According to the Brazilian Society of Medicine of Family and Community, $67 \%$ of Brazilians that depend exclusively on Brazil's precarious free healthcare system (SUS) are of African descent, and those are also the majority of patients that suffer from diabetes, tuberculosis, hypertension, and chronic kidney diseases across the country - all of which are considered aggravating factors for the development of the most serious cases of COVID-19.

This is a convenient moment for the amplification of the dialogue between the environ-mental debate and the social sciences in health. After all, in both areas, the challenge of research-ers is in finding strategies that insist on the impossibility of depleting the relevancy of structural questions on the analysis of the effects of phenomena of nature. Just as when facing an environ-mental disaster, there is the need for activating a language of analysis that takes into account the politics of the State on risk distribution to its population. When facing a pandemic, there is a need for insisting that there cannot be a pandemic without the State and, consequently, it is not possible to address the first without considering the implications on the second.

If this is the time for listening and taking seriously the advice of biologists, doctors, nurses, and public health physicians about prevention and care with the virus, it is also the mo-ment to bring back the work that was produced for over a century of social sciences focusing on epidemiology, the State and inequalities. As we have seen, the effects of the Coronavirus go way beyond the biological dynamics of the virus. Anthropological research helps us to see how epi-demics have affected us throughout history and how the debate about ways of reacting to it al-ways involve subjects that go beyond the biological agent.

\section{References}

ACSELRAD, H Justiça ambiental e construção social do risco. Desenvolvimento e meio ambi-ente, n.5, p.49-60, 2002.

BECK, U. Sociedade de risco: rumo a uma outra modernidade. Editora 34, 2011.

FOUCAULT, M. The birth of biopolitics: lectures at the Collège de France, 1978-1979. Springer, 2008.

KASPERSON, et al. The social amplification of risk: A conceptual framework. Risk analysis, n.8, v.2, p.177-187, 1988.

MOL, A. The body multiple: Ontology in medical practice. Duke University Press, 2002. 


\section{Rodrigo Toniol}

$\square$ rodrigo.toniol@gmail.com

ORCiD: https://orcid.org/0000-0002-1169-5253
Submitted on: 29/05/2020

Accepted on: 01/06/2020

2020;23:e0073

How to cite: TONIOL, R. Beyond the virus: There cannot be a pandemic without the State. Ambiente $\&$ Sociedade. São Paulo, v. 23, p. 1-6, 2020. 


\title{
Além do virus: Não há pandemia sem Estado
}

\author{
Rodrigo Toniol
}

São Paulo. Vol. 23, 2020

Ideias em debate

A época CO. VID-19: Pesquisa interdisciplinar e uma nova ética sustentável e justa
Resumo: Este artigo parte do reconhecimento da importância do Estado como agente ordenador da expe-riência da pandemia. Tal afirmação implica dois movimentos complementares. Em primeiro lugar, significa que a noção de pandemia em si tem uma genealogia. Isso é, que seu surgimento é resul-tado de um processo histórico e de configurações políticas específicas, fortemente associadas à consolidação do Estado moderno. Em segundo lugar, se o tratamento da noção de pandemia pre-cisar ser considerado com base em sua relação com o Estado, uma análise dos processos "pandê-micos" é indubitavelmente um debate político. Termino sugerindo benefícios de uma possível aproximação entre a noção de justiça ambiental e os princípios críticos para a análise da pandemia que estamos enfrentando.

Palavras-chave: Estado, justiça ambiental, natureza, Igreja

Como citar: TONIOL, R. Beyond the virus: There cannot be a pandemic without the State. Ambiente. Ambiente \& Sociedade. São Paulo, v. 23, p. 1-6, 2020.

DOI: http://x.doi.org/10.1590/1809-4422asoc20200073vu2020L3ID 


\title{
Más allá del virus: No hay pandemia sin el Estado
}

\author{
Rodrigo Toniol
}

São Paulo. Vol. 23, 2020

Ideas en debate

La época COV-

ID-19: investigación interdisciplinaria y una nueva ética sostenible y justa
Resumen: Este texto comienza con el reconocimiento de la importancia del Estado como principio de orden para la experiencia de la pandemia. Tal afirmación implica dos movimientos complementarios, aunque estos no se agotarán en las páginas siguientes. En primer lugar, significa que la noción de pandemia en sí misma tiene una genealogía. Significa que su surgimiento es el resultado de un proceso histórico y de configuraciones políticas específicas, que están fuertemente asociadas con la consolidación del Estado moderno. En segundo lugar, si el tratamiento de la noción de pan-demia debe considerarse en función de su relación con el estado, un análisis de los procesos de "pandemia" es indudablemente un debate político. Termino sugiriendo los beneficios de una posible aproximación entre la noción de justicia ambiental y los principios críticos para el análisis de la pandemia que enfrentamos.

Palabras clave: Estado, justicia ambiental, naturaleza, Iglesia.

Como citar: TONIOL, R. Más allá del virus: No hay pandemia sin el Estado. Ambiente \& Sociedade. São Paulo, v. 23, p. 1-6, 2020.

DOI: http://dx.doi.org/10.1590/1809-4422asoc20200073vu2020L3ID 